\title{
Tempo Barroco: as Visitas Pastorais dos Comissários das Ordens Terceiras no século XVIII em Minas Gerais
}

\author{
Baroque Time: Pastoral Visits of the Comissioners of the Third Orders in \\ Minas Gerais, Brazil, during the eighteenth century
}

\author{
Adriana Sampaio Evangelista*
}

\begin{abstract}
Resumo
O presente artigo tem por objetivo analisar o aparato que marcava a entrada dos comissários das ordens terceiras em suas visitas às vilas, analisando também o modo como aconteciam essas visitas pastorais. As visitações dos comissários das Ordens Terceiras de Nossa Senhora do Carmo e de São Francisco eram ocasiões que mobilizavam os irmãos destas congregações tanto no tocante aos assuntos espirituais quanto à esfera temporal. No aspecto material, as visitas demandavam grandes despesas com a realização de solenidades e hospedagem dos comissários. A visitação tinha por objetivo central assegurar a manutenção do sentido de ordem e de hierarquia que fundava as fraternidades de irmãos terceiros. Deste modo os padres visitadores deviam inspecionar e nortear a vida administrativa destas congregações e a vida particular dos terceiros seculares para verificar a sua conformação aos preceitos da moral e da fé cristã e às regras das ordens terceiras, instruir e disciplinar aqueles irmãos que houvessem cometido algum delito, coibir práticas e comportamentos desviantes. A pompa barroca das diversas cerimônias que aconteciam durante o tempo da visita concorria para suscitar o sentido de ordem e hierarquia entre os irmãos terceiros.
\end{abstract}

Palavras-chave: Ordens Terceiras; Visita Pastoral; Festa; Catolicismo; Barroco.

\begin{abstract}
This article aims to examine the apparatus that marked the entrance of the Third Orders' Commissioners on their visits to the villages, also analyzing how these pastoral visits took place. The Visitations of those Commissioners of the Third Order of Our Lady of Mount Carmel and San Francisco happened to be special occasions for the brothers of these congregations to be both materially and spiritually revived. In the material aspect, such visits demanded great costs to cover the ceremonies and the Commissioners expenses. The main purpose of the Visitation was to ensure the maintenance of a sense of order and hierarchy that originally was on the foundation of the fraternity. Thus, the Visitors should inspect and guide the administrative life of these congregations and also to help the Fathers to conform their lives to the precepts of morality and Christian faith and to the rules of the Third Order. Such visits also had the purpose to educate and to discipline those brothers who had committed some delict, and to curb practices and deviant behaviors. The pomp of the Baroque ceremonies that took place during the time of those mentioned visits finally aimed to raise the sense of order and hierarchy among all the members of Third Order of Our Lady of Mount Carmel and San Francisco.
\end{abstract}

Keywords: Third Order; Pastoral Visit; Party; Catholicism; Baroque.

Artigo recebido em 30 de junho de 2011 e aprovado em 11 de agosto de 2011.

* Doutora e mestre em Ciência da Religião (UFJF), graduada em Artes Plásticas (UFJF) e especialista em Arte e Cultura Barroca (UFOP). País de origem: Brasil. E-mail: virgmore @ terra.com.br

Horizonte, Belo Horizonte, v. 9, n. 22, p. 534-553, jul./set. 2011 - ISSN: 2175-5841 


\section{Introdução}

No século XVIII, a região aurífera das Minas Gerais foi cenário de inúmeras festividades religiosas conformadas pela estética barroca que recorria ao luxo, aos efeitos cenográficos e a pompa das cerimônias como estratégia de encantamento e de persuasão. Neste sentido a festa religiosa barroca se fundia ao profano. O sermão, a missa, a novena, os ritos processionais eram permeados pela ostentação visual, a comida, a bebida, os fogos de artifício. $\mathrm{O}$ ritual sagrado abrilhantado pela pompa barroca tinha um caráter pedagógico de reatualizar entre os fiéis os ensinamentos da doutrina católica e era uma estratégia eficaz para reforçar os sentidos de ordem e de hierarquia que presidiam as sociedades do Antigo Regime.

Os festejos promovidos pelas várias associações religiosas de leigos que se organizaram no território das Minas tomavam diversas formas abrangendo desde as celebrações religiosas ditadas pelo calendário da Igreja e pela Coroa portuguesa, às mobilizações festivas particulares realizadas para celebrar os santos de devoção, para agradecer alguma graça alcançada ou às manifestações de caráter lutuoso. Vários são os sentidos possíveis da festa barroca. Pode-se percebê-la como espaço/tempo que concorria para estreitar os laços de solidariedade entre os indivíduos agregados às associações religiosas e, ao mesmo tempo, distinguir, através da pompa barroca a condição social dos grupos e das pessoas. Nas cerimônias religiosas a exteriorização do luxo era aspecto fundamental para sinalizar o poder e a hierarquia. Neste contexto, analiso neste artigo os rituais de entradas dos comissários visitadores das ordens terceiras de Nossa Senhora do Carmo e de São Francisco de Assis da capitania das Minas Gerais. As visitas pastorais dos respectivos padres comissários destas congregações tinham por objetivo assegurar a obediência dos irmãos aos preceitos que fundavam as ordens terceiras. Procuro demonstrar que estes ritos festivos se inserem na cultura barroca. $\mathrm{O}$ aparato e o cerimonial que cercavam o padre comissário assinalavam a sua autoridade sobre os irmãos e concorriam para sedimentar entre eles o sentido de ordem e de hierarquia e que desta forma se justificaria o investimento material das ordens terceiras nestas solenidades festivas. 


\section{As Ordens Terceiras}

Na capitania das Minas Gerais, a participação leiga nos domínios do catolicismo reinante se fez presente particularmente por meio das várias associações religiosas que se espalharam pelo seu território. Foram as irmandades e ordens terceiras as principais vias de catequese da população, uma vez que a Coroa procurou limitar a entrada e a permanência de religiosos das ordens primeiras na região aurífera e proibiu a ereção de conventos nesta parte da Colônia. ${ }^{1}$ Mas a esfera de atuação dessas congregações abrangia todas as faces da vida cotidiana de seus associados tanto nos aspectos espirituais quanto temporais. Essas associações agregavam indivíduos que compartilhavam expectativas afetivas, materiais e espirituais em torno de uma mesma devoção religiosa, garantiam a seus membros socorro nos momentos de doença, de ruína financeira, de desgraça pessoal ou familiar, como prisão ou viuvez, além de reconhecimento social, amparo espiritual por meio da prestação dos devidos cuidados necessários nos últimos momentos de vida, garantindo, após a morte, o sepultamento digno no interior de uma igreja, e assegurando, por meio de sufrágios, a rápida passagem da alma pelo purgatório em direção ao paraíso (BOSCHI, 1986; FURTADO, 2003; CAMPOS, 1996; PAZ, 1968; SALES，1963). O comprometimento comum com esses encargos aproximava essas duas formas de associações religiosas de leigos que, entretanto, guardavam profundas diferenças na sua estrutura institucional, na composição social de seus membros e nos objetivos particulares que moviam suas atividades.

Ao contrário das irmandades que podiam ser criadas por qualquer cristão que assim o desejasse, a permissão para instituir ordens terceiras era privilégio apenas dos padres visitadores dessas congregações ou de terceiros seculares dissidentes, devendo receber aprovação do provincial da congregação na Colônia, cuja autoridade era delegada pela Santa Sé em Roma (BOSCHI, 1986, p. 23). Os rigorosos critérios de admissão nas ordens terceiras distinguiam essas corporações no âmbito das associações religiosas de leigos,

\footnotetext{
${ }^{1}$ As associações religiosas de leigos se diferenciam quanto a sua natureza jurídica e organizacional. As irmandades eram organizações de leigos cujos objetivos eram perpetuar uma devoção religiosa e prestar assistência a seus filiados no âmbito das necessidades espirituais e materiais. Podiam constituir-se como irmandades de devoção, de caráter informal, ou como irmandades de obrigação, cuja estrutura era submetida à jurisdição secular e eclesiástica. A par da difusão devocional e do auxílio a seus congregados, as ordens terceiras eram movidas pelo desejo de aperfeiçoamento espiritual dos irmãos e por isso se submetiam à direção de uma ordem primeira e à Santa Sé. cf. BOSCHI, 1986, p. 15-20; SALES, 1963, p. 15-18.
} 
tanto no tocante aos requisitos para a candidatura quanto ao processo de sindicância realizado para comprovar as informações, prestadas pelos pretendentes, sobre suas qualidades e condutas em relação aos preceitos cristãos, uma vez que os estatutos dessas corporações vedavam o ingresso de negros, mulatos e quaisquer outros indivíduos que não professassem o catolicismo.

As exigências de elevadas contribuições financeiras eram outro fator distintivo entre os institutos de terceiros seculares e as irmandades. As altas despesas com joias de entrada, profissão, anuais e patente, entre outros dispêndios, dificultavam o ingresso de muitos homens e mulheres nas ordens terceiras.

A observância aos rituais era bastante louvada nessas congregações como via espiritual de salvação da alma, fundamento central na vida cotidiana dos terceiros seculares carmelitas e franciscanos. ${ }^{2}$ Nesse sentido, destaca-se o ritual de profissão a que se comprometiam os irmãos no ato de sua entrada.

Os terceiros do Carmo e de São Francisco seguiam um calendário religioso rigoroso que abarcava, além das festividades em honra aos santos mais importantes e aos padroeiros, intensa participação nas solenidades da Semana Santa e nos ritos quaresmais, organizações de vias-sacras, regulares práticas espirituais de penitência, oração mental e preparação espiritual pelo noviciado, que culminava em solene cerimônia de profissão, quando então o candidato era finalmente agregado ao quadro funcional das ordens terceiras. A preocupação com o aprimoramento espiritual dos seus membros foi o aspecto fundamental que distinguiu esses sodalícios das irmandades e que conformou a vivência religiosa da fé cristã entre os terceiros de São Francisco e do Carmo, marcada pelo apego a um ritualismo severo. O irmão terceiro procurava seguir no estado secular um estilo de vida inspirado pelos religiosos franciscanos e carmelitas, empenhando-se no cumprimento rigoroso das penitências e dos jejuns, na prática constante da oração mental e dos exercícios espirituais, na frequência da confissão e da comunhão. Ainda que a vida cotidiana na sociedade mineradora estimulasse o abrandamento do rigor dessas práticas e, muitas vezes, o seu descumprimento (EVANGELISTA, 2010, p. 91-95, 107), a busca da perfeição espiritual foi, entre os irmãos terceiros, símbolo de dignificação social e espiritual. Conferia prestígio ao indivíduo numa sociedade estratificada marcada pelo apreço à hierarquia e aos

\footnotetext{
${ }^{2}$ Esta questão foi amplamente discutida em: EVANGELISTA, 2010.
} 
privilégios e ancorada num catolicismo contrarreformista, que exaltava a lembrança constante da morte e do juízo final. Os terceiros seculares desfrutavam ainda de privilégios de caráter espiritual na forma de indulgências aplicadas à salvação das suas almas.

A concepção sacramental do rito confirmava-se nas diversas celebrações religiosas promovidas pelos terceiros, dentre as quais se destacam as visitas dos comissários visitadores das congregações de irmãos leigos de São Francisco e de Nossa Senhora do Carmo da Vila de São João del Rei, da Vila do Sabará e de Vila Rica, que vou abordar em particular neste estudo. Como veremos, a pompa barroca que marcava as várias cerimônias que aconteciam durante as visitas era recurso fundamental para o seu bom êxito.

\section{A ordem no céu e na terra}

Segundo a ordem de importância na escala hierárquica que regia a composição funcional da mesa administrativa dessas congregações, o comissário visitador era a autoridade máxima no que tangia à esfera do sagrado: "é a primeira cabeça no espiritual desta Venerável Ordem, e outrossim, em todas as Mesas". ${ }^{3}$ Se os estatutos de 1754 da congregação dos terceiros seculares franciscanos de Vila Rica determinavam que o comissário fosse um religioso professo da ordem primeira designado pelo provincial, na prática essa regra nem sempre foi seguida. Em 1758, entre as alterações feitas nos estatutos, estabeleceu-se que o cargo poderia ser ocupado por um clérigo e irmão professo exclusivamente da Ordem Terceira de São Francisco, desimpedido de empregos públicos, para que pudesse arcar com as inúmeras responsabilidades de seu ofício, eleito pela mesa administrativa da Ordem com a aprovação do Provincial. ${ }^{4} \mathrm{O}$ cargo de comissário era remunerado, e o valor do salário a mesa administrativa deveria arbitrar consoante o "merecimento de seu trabalho". Frei Manoel do Livramento justificava que "em razão da multiplicidade das ordens terceiras que há nestas Minas não possamos mandar para cada uma delas um religioso que, sendo comissário, assista com os irmãos terceiros aos ofícios louváveis da dita ordem dirigindo-os ao caminho da salvação" e que por esta razão era

\footnotetext{
${ }^{3}$ AOTSF/OP - vol. 204. Estatutos da Ordem Terceira de São Francisco de Assis de Vila Rica - 1754-1756, cap. 15, ss. 5. A grafia de todos os documentos foi atualizada para facilitar a leitura.

${ }^{4}$ AOTSF/OP - vol. 206. Estatutos da Ordem Terceira de São Francisco de Assis de Vila Rica - 1758-1761, cap. 14, ss. 4, f. 10; AOTSF/OP - vol. 206. Estatutos da Ordem Terceira de São Francisco de Assis de Vila Rica - 1758-1761, cap. 14, ss. 3, f. 11v.
} 
necessário nomear um padre, irmão da congregação dos terceiros franciscanos, para cumprir com essas obrigações. ${ }^{5}$ Ser irmão professo na ordem dos terceiros seculares era condição imprescindível para que o mesmo sacerdote fosse nomeado comissário, assim como a observância estrita do tempo de noviciado a que este deveria submeter-se, pois, como alegava mais uma vez frei Manoel do Livramento, por experiência que a ordem terceira já havia tido, a dispensa do prelado de fazer o ano de noviciado comprometia a direção nos exercícios espirituais dos irmãos terceiros. ${ }^{6}$

Nos primeiros anos de estabelecimento das ordens terceiras na região mineradora, o comissário visitador tinha jurisdição espiritual sobre todas as funções que se relacionassem, direta ou indiretamente, ao campo do sagrado. Desse modo, cabia ao comissário visitador deliberar e esclarecer dúvidas sobre questões de caráter espiritual assim como inspecionar a vida administrativa das fraternidades de irmãos terceiros também nos seus aspectos temporais. Ao comissário tocava verificar a organização dos livros de registros da congregação, o asseio e a decência dos utensílios e alfaias necessários ao serviço litúrgico, o guizamento da capela, assim como a fiscalização da situação financeira da ordem terceira. Também lhe era permitido participar das decisões de caráter temporal junto à mesa administrativa, com direito a voto consultivo, e arbitrar nas situações de empate. Entretanto, com o passar dos anos, a sua participação nas reuniões ordinárias da mesa administrativa passou a ser controlada e a sua área de atuação foi restringida às funções de caráter exclusivamente espiritual e subordinada às decisões da mesa administrativa e à autoridade do irmão ministro. ${ }^{7}$ Desse modo, na prática, o ofício de comissário visitador compreendia a direção espiritual dos terceiros seculares nas disciplinas e penitências, nos exercícios espirituais e na condução da oração mental, a celebração da eucaristia, a confissão e a comunhão dos irmãos e outras tarefas de cunho espiritual. Ao limitar as funções do cargo de comissário, as mesas administrativas procuravam assegurar sua independência em relação à jurisdição dos provinciais, o que foi motivo para vários desentendimentos entre estes e as congregações seculares franciscana e carmelita da região aurífera.

\footnotetext{
${ }^{5}$ AOTSF/SJDR - Livro de termos, deliberações e pastorais da Ordem Terceira de São Francisco de São João del Rei - 1762, f.(?).

${ }^{6}$ AOTSF/SJDR - Livro de termos, deliberações e pastorais da Ordem Terceira de São Francisco de São João del Rei, f. 67.

${ }^{7}$ AOTSF/OP - vol. 206. Estatutos da Ordem Terceira de São Francisco de Assis de Vila Rica - 1758-1761, cap. 14 , ss. 2 , f. 11.
} 
Os estatutos previam uma visita anual do comissário à ordem terceira para averiguar, orientar e punir, se necessário fosse, os irmãos que se desviassem do cumprimento das regras estabelecidas nos capítulos dos estatutos assim como para informar-se da administração espiritual e temporal da congregação. Essas visitas não tinham um caráter inquisitorial, mas visavam conferir e corrigir a conduta moral dos irmãos terceiros, a observância das normas, a preservação do patrimônio, o zelo com a fábrica da capela e as finanças das ordens terceiras, bem como orientar os irmãos quanto à administração espiritual e temporal da congregação e informar aos provinciais sobre a situação dos institutos seculares na capitania das Minas Gerais. As visitas pastorais tinham o firme propósito de assegurar o aprimoramento espiritual dos irmãos e a manutenção da ordem dentro da congregação, princípio este fundamental para se alcançar o estado de perfeição espiritual que, segundo a mística cristã, era o caminho que levava à salvação da alma.

A visão sacramental de mundo alicerçada no sentido de ordem e hierarquia presidiu não só as atividades de caráter religioso, mas também a vida cotidiana das pessoas nas Minas setecentistas. A estrutura organizacional das ordens terceiras era fundada na ideia de hierarquia e ordem, alegoricamente representada pela imagem do corpo místico que difundia entre os irmãos terceiros a disposição para a obediência e a submissão como vias fundamentais para se alcançar a Deus (MARTINS, 2009, p. 69-84). Essa concepção faz eco aos escritos de São Paulo, que recorreu à imagem de corpo para construir a ideia de Cristandade fundada na ordem e na hierarquia: a desobediência e a desordem, além de comprometerem o funcionamento do organismo, representavam uma transgressão à harmonia estabelecida por Deus: "De modo que aquele que se revolta contra a autoridade, opõe-se à ordem estabelecida por Deus". 8 Esse conceito era recorrente nas orientações pastorais dos comissários visitadores, nos manuais de devoção, nos sermões e nas imagens que circulavam entre os irmãos terceiros. Por diversas vezes os comissários visitadores atestaram em suas pastorais a necessária observância da hierarquia e da ordem como vias para se ascender ao sagrado. Frei Francisco de Cerqueira Campos, em carta pastoral de 13

\footnotetext{
${ }^{8}$ Rom 12, 2. Essa mesma idéia de ordo vai se estender posteriormente à sociedade. Essa noção de universo naturalmente ordenado sustentou as sociedades estamentais do Antigo Regime favorecendo a manutenção das divisões e distinções sociais entre os grupos de indivíduos. Ver a respeito CAMPOS, 2004, p. 193-215. Cf. as cartas de Paulo: 1 Cor 12, 27-28; 1 Cor 12, 27-28; Rom 12, 5; Ef 1, 22; 4, 15; 5, 23; Cl 1, 18; $2,19$.
} 
de outubro de 1769, dirigida aos terceiros franciscanos da Vila de São João del Rei, escreveu: "Fazemos saber a Vossas Mercês que visitando esta Venerável Ordem achamos ser muito necessária algumas advertências para a boa conservação deste corpo místico...". 9 O comissário dos terceiros de São Francisco de Vila Rica deixou registrado um capítulo geral de correção e penitência dos irmãos que haviam incorrido em falta grave ou desobediência, assim como orientações normativas para a sua conduta: “...que se conheça que é ordem, a que se deve praticar na terra, assim como se usa no céu, onde os anjos se não misturam com os arcanjos, nem os querubins, com os serafins, mas antes todos formados em seus lugares competentes, louvam ao Rei da glória". ${ }^{10}$

No dicionário de Raphael Bluteau, muito popular no século XVIII tanto em Portugal como na capitania das Minas, o termo ordem se abre no sentido de "Disposição, assento, ou colocação das coisas no lugar, que lhe convém” (BLUTEAU, 1713, p.102). Através da metáfora do corpo formado pelo harmonioso funcionamento de várias partes, Paulo formulou o conceito de corpo da Igreja composto de diversos membros, cada qual com uma função particular que, exercida de modo ordenado e em sua posição adequada, resultaria no benefício tanto do corpo quanto de cada membro: ${ }^{11}$

Com efeito, o corpo é um e, não obstante, tem muitos membros, mas todos os membros do corpo, apesar de serem muitos, formam um só corpo. Assim acontece também com Cristo. Pois fomos batizados num só Espírito para ser um só corpo, judeus e gregos, escravos e livres, e todos bebemos de um só Espírito. O corpo não se compõe de um só membro, mas de muitos. Se o pé disser: Mão eu não sou, logo não pertenço ao corpo, nem por isto deixará de fazer parte do corpo. E se a orelha disser: Olho eu não sou, logo não pertenço ao corpo, nem por isto deixará de fazer parte do corpo. Se o corpo todo fosse olho, onde estaria a audição? Se fosse todo ouvido, onde estaria o olfato? (1 Cor 12, 12-17).

Na concepção de São Paulo, faz-se necessária a distinção de valor entre os membros do corpo, o estabelecimento de uma hierarquia entre eles assim como o seu ordenamento segundo esse valor, mas todos são fundamentais para o funcionamento desse organismo:

\footnotetext{
${ }^{9}$ AOTSF/SJDR - Livro de termos, deliberações e pastorais da Ordem Terceira de São Francisco de São João del Rei, f. $87 \mathrm{v}$.

${ }^{10}$ AOTSF/OP - vol. 513. Patentes. Ordem Terceira de São Francisco de Assis de Vila Rica - 1745 a 1788 , doc. avulsos, f. $15 \mathrm{v}$.

${ }^{11}$ Essa mesma ideia de ordo vai se estender posteriormente à sociedade. Essa noção de universo naturalmente ordenado sustentou as sociedades estamentais do Antigo Regime favorecendo a manutenção das divisões e distinções sociais entre os grupos de indivíduos. Ver a respeito CAMPOS, 2004, p.193-215.
} 
Ora, vós sois o corpo de Cristo e sois os seus membros, cada um por sua parte. E aqueles que Deus estabeleceu na Igreja são, em primeiro lugar, apóstolos; em segundo lugar, profetas; em terceiro lugar, doutores [...] Vêm, a seguir, os dons dos milagres, das curas, da assistência, do governo e o de falar diversas línguas (1 Cor 12, 27-28; 1 Cor 12, 27-28; Rom 12, 5; Ef 1, 22; 4, 15; 5, 23; Cl 1, 18; 2, 19).

A desobediência e a desordem, além de comprometerem o funcionamento do organismo, representam uma transgressão à harmonia estabelecida por Deus: "De modo que aquele que se revolta contra a autoridade, opõe-se à ordem estabelecida por Deus". ${ }^{2}$ Do sentido de ordem decorria a percepção de uma dependência mútua entre o plano espiritual e o terreno.

\section{A pompa barroca das visitas pastorais}

Os estatutos da Ordem Terceira de São Francisco de 1754 de Vila Rica informavam como as visitas eram feitas. ${ }^{13}$ No dia da Porciúncula, ao final da procissão, todos os irmãos terceiros se reuniam na capela dos exercícios para ouvir um sermão do comissário visitador. Este então designava entre os congregados um irmão para servir de secretário da visita.

No dia seguinte, eram convocadas as testemunhas para depor sobre os irmãos de vida desregrada que vivessem em culpa. Registradas as denúncias, o rol com os nomes dos culpados era guardado, sob chave, numa gaveta do bofete, na casa do consistório até que as penitências fossem aplicadas. A determinação das punições cabia ao padre visitador, mas sua aprovação era subordinada à votação secreta dos oficiais da mesa administrativa que declaravam sua decisão, sem terem ciência dos nomes dos acusados, baseados somente nos motivos das acusações. Os oficiais depositavam favas brancas ou negras num vaso, que, ao final da votação, era virado sobre a mesa para que os votos fossem contados. Os nomes dos irmãos denunciados, dos denunciantes e das testemunhas e as sentenças proferidas eram registradas pelo irmão terceiro secretário da visita, e esse rol era guardado em uma gaveta com duas chaves, uma das quais ficava sob a guarda exclusiva do secretário e a outra, do padre comissário. No dia do capítulo de culpas, os irmãos considerados culpados eram

\footnotetext{
12 Rom, 12, 2.

${ }^{13}$ AOTSF/OP - vol. 204. Estatutos da Ordem Terceira de São Francisco de Assis de Vila Rica - 1754-1756, cap. 16 , ss. 1.
} 
convocados e as sentenças, proferidas. Então o papel com a relação dos nomes dos irmãos e com as acusações feitas era queimado à luz de vela perante a mesa reunida e dava-se início à aplicação das penitências. No caso de algum oficial da mesa administrativa ser acusado, seu nome não era registrado naquele rol, mas lançado no Livro dos Culpados para que a mesa administrativa futura aplicasse a penitência determinada. A expulsão da ordem terceira era o castigo mais severo prescrito somente nos casos considerados mais graves, como o concubinato, homicídio ou, após três admoestações, sem que houvesse emenda do acusado. Também eram sujeitos a denúncias aqueles irmãos que praticassem "danças pouco honestas e indecentes", que frequentassem casas públicas de jogos e tabernas, que usassem o hábito de terceiro secular nesses lugares ou que fossem remissos e infrequentes nos atos públicos da congregação. As penitências eram rituais de submissão e humildade que deveriam realizar os irmãos considerados culpados perante o comissário visitador e a mesa da ordem terceira. Uma penitência muito aplicada era o retorno do irmão terceiro professo à casa do noviciado por determinado tempo de modo que se colocasse "debaixo da direção do Irmão Mestre, ocupando-os em todos os exercícios dos Irmãos Noviços". ${ }^{14}$ O objetivo dessa punição era que o irmão desobediente fosse reeducado nos preceitos de submissão e humildade.

Certamente, a chegada do comissário visitador na vila instaurava um clima de apreensão e desconfiança entre os irmãos terceiros. Entretanto, a ocasião ao mesmo tempo era de júbilo, festejada com toda a pompa tanto nos atos públicos como nas cerimônias internas das congregações seculares do Carmo e de São Francisco. Como veremos, a ocasião solene das visitas pastorais demandava um considerável investimento das mesas administrativas em recursos materiais.

As visitas pastorais correspondiam a um tempo particular no calendário de celebrações das ordens terceiras. Segundo os estatutos de 1754 dos irmãos franciscanos de Vila Rica, ela deveria ser anual, salvo se houvesse necessidade de mais visitas. ${ }^{15}$ Segundo os mesmos estatutos, a visita tinha um tempo determinado. Iniciava-se com o dia da

\footnotetext{
${ }^{14}$ AOTSF/OP - vol. 204. Estatutos da Ordem Terceira de São Francisco de Assis de Vila Rica - 1754-1756, cap.16, ss. 2. No dia 2 de agosto celebram os irmãos terceiros franciscanos o dia da Porciúncula ou de Nossa Senhora dos Anjos, padroeira da ordem seráfica. A festa das Chagas do Patriarca São Francisco é comemorada no dia 25 de setembro.

${ }^{15}$ AOTSF/OP - vol. 204. Estatutos da Ordem Terceira de São Francisco de Assis de Vila Rica - 1754-1756, capitão15, ss. $1^{\circ}$, f. 40.
} 
Porciúncula e findava na véspera do dia das Chagas do Patriarca São Francisco. ${ }^{16}$ A reforma dos estatutos aprovada em 1761 transferiu a data da visita para o começo do Advento e seu término para o início da Quaresma, em um dos domingos desse tempo. ${ }^{17} \mathrm{~A}$ chegada do comissário visitador era precedida de anúncio e convocação, pelo secretário da ordem terceira, dos irmãos que haviam de fazer suas denúncias. ${ }^{18}$ As visitas costumavam durar semanas uma vez que durante o tempo em que permanecia na vila, o reverendo padre comissário visitador se dedicava a diversas atividades voltadas para a direção da vida espiritual e temporal dos irmãos terceiros.

A entrada do comissário visitador era revestida de pompa e cerimônia ao gosto da ostentatio barroca, como revela o registro feito pelo irmão secretário, da entrada e visita que fez frei Manoel do Livramento à Ordem Terceira de São Francisco, da Vila de São João del Rei: ${ }^{19}$

\begin{abstract}
Aos quatro do mês do mês[sic] de setembro de 1765 o Nosso Reverendíssimo Comissário Visitador frei Manoel do Livramento [...] fez a sua entrada, e deu princípio a sua visita nesta nossa Igreja, e venerável congregação da vila de São João del Rei, e sua comarca do Rio das Mortes assistindo a tudo o Nosso Caríssimo irmão atual o Doutor Antonio José de Melo, Definitório, e ma[...] deste Seráfico Rebanho, não só a dar lhe a posse devida mas também a recebê-lo como se recebeu com plena comunidade de cruz alçada, e mais cerimônias, que nesta dita venerável congregação se costumam tributar a nossos legítimos prelados $[\ldots .]^{20}$
\end{abstract}

O investimento material nas cerimônias de entradas solenes se justificava pela força da dimensão simbólica evocada por esse ritual. A antiguidade e a regularidade das solenidades de entradas assim como seu caráter hierárquico e o aparato que marcavam essas cerimônias criavam um efeito cenográfico inerente ao espírito barroco e por esta razão, no sentido maravaliano, tinham a capacidade de mover os espectadores, (MARAVALL, 1990), e dessa forma preservar a ordem e a hierarquia (CARDIM, 2001, p. 93-124; ÁVILA, 1994, p.79-85).

\footnotetext{
${ }^{16}$ AOTSF/OP - vol. 204. Estatutos da Ordem Terceira de São Francisco de Assis de Vila Rica - 1754-1756, cap. 16, ss. 1, f.40.

17 AOTSF/OP - vol. 206. Estatutos da Ordem Terceira de São Francisco de Assis de Vila Rica - 1758-1761, cap. 13, f. 10 .

18 AOTSF/OP - vol. 224. Visitas. Ordem Terceira de São Francisco de Assis de Vila Rica - 1761-1765,

${ }^{19}$ Sobre o sentido que as festividades e o cerimonial das entradas episcopais têm de reafirmação do poder eclesiástico ver PAIVA, 2001, p. 79-93.

${ }^{20}$ AOTSF/SJDR - Livro de termos, deliberações e pastorais da Ordem Terceira de São Francisco de São João del Rei, f. 58.
} 
A solenidade que marcava a chegada do comissário visitador nas fraternidades do Carmo e de São Francisco de Vila Rica ainda persistiu nos anos seguintes como atestam outros registros no mesmo livro. Por ocasião da visita de 31 de agosto de 1770 à congênere da Vila de São João del Rei, frei Antonio Antunes de Campos “...foi recebido com pronta obediência e humilhação de vida o predito muito Reverendo Comissário Visitador e se lhe deu a devida posse com todas as cerimônias do estilo[...]". ${ }^{21}$ Outra visita já havia sido feita anteriormente à mesma congregação em 7 de fevereiro de 1770 pelo mesmo prelado. Em 6 de fevereiro de 1771, a entrada de frei Antonio Antunes de Campos foi marcada com o mesmo aparato:

foi recebido com pronta obediência e humilhação de vida a pred[...] Muito Reverendo Comissário Senhor Visitador e se lhe deu a devida posse com todas as cerimônias do estilo e neste mesmo dia deu princípio a sua Visita passando para esse efeito as ordens necessárias $[\ldots . .]^{22}$

Oito meses depois, o reverendo frei Antonio Antunes de Campos retornava à Vila de São João del Rei para nova visita pastoral na Ordem Terceira de São Francisco, onde foi recebido solenemente. ${ }^{23} \mathrm{E}$ ainda em 10 de setembro de 1772 , quando retornou à mesma vila, foi acolhido com a pompa que a circunstância requeria. ${ }^{24}$

Em sua obra relativa à Ordem Terceira do Carmo de Sabará, Zoroastro Vianna Passos revela um documento bastante esclarecedor quanto ao ritual que marcava a chegada do comissário visitador. Trata-se das determinações deixadas por frei José de Jesus Maria durante sua visita aos irmãos terceiros daquela congregação em 1761 e registradas no livro de termos (PASSOS, 1940, p.18-19).

O sentido de hierarquia e ordem de que se revestia o cerimonial se fazia presente nas opas usadas pelos irmãos terceiros e no escalonamento dos irmãos segundo seu grau de importância dentro da congregação:

${ }^{21}$ AOTSF/SJDR - Livro de termos, deliberações e pastorais da Ordem Terceira de São Francisco de São João del Rei, f. 91.

${ }^{22}$ AOTSF/SJDR - Livro de termos, deliberações e pastorais da Ordem Terceira de São Francisco de São João del Rei, f. 93.

${ }^{23}$ AOTSF/SJDR - Livro de termos, deliberações e pastorais da Ordem Terceira de São Francisco de São João del Rei, f. 93.

${ }^{24}$ AOTSF/SJDR - Livro de termos, deliberações e pastorais da Ordem Terceira de São Francisco de São João del Rei, f.[?]. 
Chegado que seja o dito Reverendo Visitador a esta vila irá o Reverendo Padre Comissário, irmão Prior, e o mais definitório da Mesa com seus hábitos vestidos dar-lhe as boas vindas, mostrando nesta ação serem filhos obedientes reconhecendo o seu Prelado como seu Pastor, e assim se seguirão os mais irmãos indo cada um por sua ordem [...] (PASSOS, 1940, p. 18).

A visita era anunciada com antecedência através de uma carta aos irmãos que era fixada na sacristia da capela da ordem terceira, de modo que todos se preparassem espiritual e materialmente para a recepção:

Determinado o dia da sua posse terá o irmão Vigário da Capela da vossa ordem preparada, e ornada como dia festivo, tendo sobre o presbitério uma cadeira da parte do Evangelho com toda a decência para o Reverendo Padre Visitador nela se assentar a seu tempo, e nos degraus da mesma capela uma alcatifa com seu coxim para a entrada do Reverendo Padre Visitador, e nesse mesmo dia irão com o Vice-Comissário, e alguns dos irmãos mais dignos fora da Meza [o resto da página inutilizado] Comissario lhe fará entrega da estola, e do izope de água benta, e os Irmãos todos com tochas acesas, juntamente a Mesa [...] (PASSOS, 1940, p. 18).

Observamos nesta passagem a relevância dos objetos rituais que assinalavam a solenidade e a sacralidade da ocasião e a condição superior do comissário visitador dentro da hierarquia da ordem terceira atestada pelo aparato que o cercava exteriorizando o seu poder.

Como em todas as cerimônias e rituais promovidos pelas sociedades barrocas do Antigo Regime, a música era elemento fundamental para compor o cenário. A estética barroca valoriza a música na medida em que ela era recurso fundamental para envolver e encantar o espectador. Em 1763, os irmãos terceiros de São Francisco de Vila Rica despenderam 7\$200 rs com a música encomendada especialmente para aquela ocasião. Segundo os registros deixados pelos terceiros do Carmo de Sabará, antes de subir os degraus do altar-mor, o reverendo visitador cantava o Te Deum Laudamus e prosseguia-se a cerimônia com música ou o cantochão (PASSOS, 1940, p. 18).

Os gestos rituais relembravam, a todo momento, a condição de submissão que deveria ser rigorosamente observada:

e chegado que seje aos degraus do altar-mor, pondo-se de joelhos o Padre Visitador se porá toda a ordem também de joelhos até que o Padre Visitador se levante, e se assente na cadeira para mandar ler a sua patente, e que todos estarão assentados cada um em seus lugares [...] irá o Reverendo Padre Comissário beijar o escapulário do Reverendíssimo Padre Visitador com o joelho em terra, e 
seguir-se-á o irmão Prior, e toda Mesa definitória cada um por sua vez, e prosseguirá toda a ordem de dois em dois com as mãos recolhidas de baixo do escapulário;e acabado este ato farão o que determinar o Reverendíssimo Padre Visitador [...] (PASSOS, 1940, p. 18-19).

O final da cerimônia reafirmava novamente, através da música, o caráter festivo de júbilo da solenidade de entrada do comissário visitador e assinalava publicamente a toda a população da vila a relevância do acontecimento: "e quando o dito recolher para a sua casa lhe repicarão os sinos, e o acompanhará toda ordem...”.

A hospedagem e a alimentação do comissário visitador corriam por conta das mesas administrativas das ordens terceiras:

Advertimos aos nossos caríssimos irmãos terceiros desta Venerável Ordem do Sabará, que quando vier algum Religioso da nossa ordem da Província do Rio de Janeiro adonde estão sujeitas estas Ordens Terceiras das Minas por Visitador das ditas Ordens Terceiras, será obrigada esta ordem a dar-lhe uma casa para sua aposentadoria, sustentando-o enquanto existir no serviço da mesma ordem. (PASSOS, 1940, p. 18).

Frei José de Jesus Maria, em carta de 1761 aos terceiros carmelitas de Vila Rica anunciando sua visita, requisitava que "...tendo vossas caridades preparada uma casa, ou lugar para recolher este pobre humilde e indigno Filho da Mãe de Deus...". 25

Documento bastante elucidador no que concerne à descrição do aparato que cercavam as visitas pastorais é um rol de algumas despesas feitas pelo secretário da congregação de São Francisco em Vila Rica no ano administrativo de 1778 para 1779, por ocasião da chegada do comissário. ${ }^{26}$ Por esse documento, sabemos que o irmão secretário alugou uma cozinheira e um preto "para serventuário da cozinha" pelos 18 dias que durou a visita. Dentre a relação de compras efetuadas para a ocasião, além de lenha e vela de fumo para o funcionamento do fogão, encontram-se inúmeros utensílios de cozinha como gamelas, panelas, facas, vela de fumo e lenha. ${ }^{27} \mathrm{E}$ o que se comia numa ocasião especial como esta? Cabia à mesa administrativa da ordem terceira providenciar um cardápio

${ }^{25}$ AOTC/OP - vol.2487. Carta de Visitação - Ordem Terceira de Nossa Senhora do Carmo de Vila Rica. 1761.

${ }^{26}$ AOTSF/OP - vol. 277. folhas avulsas. Receita e Despesa da Ordem Terceira de São Francisco de Assis de Vila Rica - 1738 a 1968. Não foi possível verificar se a casa reservada para acomodar o comissário visitador pertencia à Ordem Terceira de São Francisco - proprietária que era de inúmeros imóveis em Vila Rica - ou se era alugada especialmente para a ocasião.

${ }^{27}$ Com relação aos utensílios, não pude determinar se se tratava de um acréscimo dos bens que a ordem terceira já possuía ou de aquisição feita unicamente para o período da visita. 
requintado ou a ocasião requeria maior sobriedade? A lista de gêneros alimentícios que encontrei nos registros do sodalício franciscano de Vila Rica não deixa dúvidas quanto ao caráter festivo da estadia do comissário visitador marcada pela fartura. ${ }^{28}$ Também a Ordem Terceira do Carmo de Vila Rica deixou registradas num caderno as várias despesas feitas na venda de João de Almeida entre 1750 a 1752, tais como amêndoas, manteiga, bacalhau, peixe, vinho, queijo, aguardente, açúcar, paio, camarão, mel, sabão do Reino... ${ }^{29}$ As carnes, o pão, o peixe seco, o bacalhau, as especiarias, a manteiga, ovos, azeitonas, legumes e hortaliças já estavam presentes largamente na mesa do português medieval (ARNAUT, 1986, p.12-46). Da mesma forma, o vinho fazia parte das refeições diárias dos portugueses no Reino assim como na Colônia (MAGALHÃES, 2004, p.30-43). Era consumido diariamente até mesmo por indicação medicinal (ALGRANTI, 1997, p.128). Também a aguardente, principalmente a importada de Portugal, era bastante apreciada e seus benefícios para a saúde reconhecidos (SCARANO, 2001, p.468-469). ${ }^{30}$

Não encontrei registro de compras de utensílios mais requintados como louças finas, do Porto ou das Índias, talheres, pratos, copos de vidro, sopeiras comuns àqueles indivíduos mais abastados da capitania como atestam alguns inventários, o que me permite supor que a ordem terceira possuía esses artefatos adquiridos especialmente para ocasiões festivas como a hospedagem do comissário visitador. Outro registro que merece nossa atenção foi "de

\footnotetext{
${ }^{28} \mathrm{Na}$ lista feita pelo secretário da Ordem Terceira de São Francisco de Vila Rica consta: frango, galinha, bacalhau, feijão, ovos, azeite, vinagre, frutas e legumes variados, azeitona, toucinho, carne, feijão, açúcar, passas, farinha de mandioca, letria, passas, manteiga do reino, chocolate, aguardente do Reino dentre outros.

${ }_{29}$ AOTC/OP - vol. 2564. Borrador da Ordem Terceira de Nossa Senhora do Carmo de Vila Rica. 1734 a 1755 .

${ }^{30}$ No processo de colonização do Brasil, o português transplantou para o novo território as preferências e os hábitos alimentares de herança medieval, introduziu na Colônia diversas espécies vegetais e animais comuns nas terras lusitanas e divulgou técnicas culinárias e livros de receitas (MAGALHÃES, 2004, p. 110). Como lembra Magalhães, ao final do século XVII, "a cozinha portuguesa no contexto europeu, não se ajustava aos padrões refinados franceses dos séculos XVII e XVIII: a carne de caça era bastante apreciada, raros eram os talheres e a mesa primava pela quantidade de comida (MAGALHÃES, 2004, p. 111). A cozinha daqueles indivíduos mais abastados era provida com produtos reinóis comercializados em toda a colônia tais como o bacalhau, a pimenta do reino, o vinagre, o vinho, o presunto e o paio. Já a dieta cotidiana da maior parte da população era composta basicamente por feijão, milho, fubá, arroz, carne, frutas e hortaliças (ALGRANTI, 1997, p. 124). No período colonial, a farinha de trigo era gênero de luxo adquirido nos mercados da Europa e de São Paulo. No século XVIII, a ideia de civilidade e os bons hábitos à mesa ditados pela sociedade francesa como o uso de utensílios individuais seduzia diferentes classes sociais na Europa e em Portugal. Entretanto, "essa evolução dos costumes não foi assimilada rapidamente no Brasil" (MAGALHÃES, 2004, p.113; ALGRANTI, 1997, p.122), onde os dedos levavam a comida diretamente à boca. Na capitania das Minas Gerais, o consumo de artefatos domésticos requintados estava diretamente ligado ao sucesso da atividade mineratória cujos lucros permitiam a sua aquisição.
} 
doce que se comprou em toda assistência". ${ }^{31}$ Ao analisar os livros de contas do Seminário de Mariana, Sônia Maria de Almeida Magalhães identificou as iguarias, doces presentes na mesa dessa instituição e que certamente faziam parte da culinária local. Doces de frutas como marmeladas e goiabadas eram bastante apreciados, mas, em ocasiões especiais, eram preferidas as sobremesas tradicionais do Reino como manjar branco, aletria e pão de ló, que provavelmente estiveram presentes nas refeições do comissário visitador durante sua estadia em Vila Rica (ARNAUT, 1986, p.116; MAGALHÃES, 2004, p. 97-98).

A relação dos gastos acima mencionados relativos à hospedagem do comissário visitador da Ordem Terceira de São Francisco de Vila Rica totalizou a avultada quantia de 64 oitavas 3/4 e 4 vinténs de ouro. ${ }^{32}$ A congregação ainda arcou com os gastos que o dito reverendo comissário visitador fez na estalagem da vila. Havia ainda as despesas com as missas realizadas na capela da ordem terceira por ocasião da visita pastoral, tais como azeite de mamona para a lâmpada, cera, vinho, hóstias, a remuneração do comissário e, às vezes, do seu acompanhante.

Pode-se ver que a presença do comissário visitador na vila representava uma despesa avultada com a qual a congregação nem sempre tinha condições financeiras de arcar. Em certa ocasião, por exemplo, os terceiros franciscanos da Vila de São João del Rei, esquivando-se de acolher o Comissário, alegaram em carta ao provincial, frei José dos Anjos Passos, no Convento do Rio de Janeiro, a "impossibilidade em que se acham para contribuir com as despesas indispensáveis a uma visita...".33

O consumo frequente de peixe seco e de bacalhau, registrado nos registros deixados pelo irmão secretário, atesta que a mesa administrativa da Ordem Terceira do Carmo de Vila Rica deveria observar as prescrições de jejum e restrição de carne, tão valorizadas nas determinações dos estatutos dessa congregação. Já a relação de gêneros alimentícios adquiridos pela Ordem Terceira de São Francisco de Vila Rica informa que, ao menos durante as visitas pastorais, a abstinência deveria ser respeitada. Ainda que não se possa comprovar que a abstinência de carne fosse seguida pelos irmãos terceiros em seu

\footnotetext{
${ }^{31}$ AOTSF/OP - vol. 277. folhas avulsas. Receita e despesa da Ordem Terceira de São Francisco de Assis de Vila Rica - 1778 / 1779.

${ }^{32}$ Não pude saber se nos 18 dias em que o comissário visitador esteve em Vila Rica a congregação teve outras despesas com a sua hospedagem.

${ }^{33}$ AOTSF/SJDR - Livro de termos, deliberações e pastorais da Ordem Terceira de São Francisco de São João del Rei.
} 
cotidiano, verificamos que havia uma preocupação da mesa administrativa em observar as restrições alimentares em determinadas situações.

A comida é parte importante da festa. A alimentação é uma atividade cultural que envolve gestos, etiqueta, utensílios próprios, escolha de alimentos, horários definidos, interdições, sociabilidades e muitas vezes é condicionada por fatores religiosos. Era tradição já no período colonial, e ainda hoje perdura, a Ordem Terceira de São Francisco distribuir cartuchos de amêndoas aos padres, crianças e demais irmãos que participavam das procissões realizadas pela congregação, assim como oferecer bolinhos aos clérigos que tomavam parte nas missas rezadas no dia da Porciúncula. ${ }^{34} \mathrm{~A}$ ideia da hospitalidade mineira estava intimamente associada à fartura à mesa, como testemunham os relatos dos viajantes estrangeiros que atravessaram o território das Minas Gerais no século XIX (MAGALHÃES, 2004, p. 85-86).

$\mathrm{O}$ valor dado à abundância de alimento no contexto da sociedade mineira colonial se insere na pompa barroca que marcava determinadas ocasiões como as celebrações religiosas. A mesa farta notabilizava no território das coisas mundanas, assinalando a condição social do indivíduo e do grupo, assim como no âmbito espiritual a privação do alimento distinguia aqueles que buscavam um aprimoramento espiritual através do jejum e da abstinência.

\section{Considerações finais}

A presença do comissário visitador entre os irmãos terceiros era uma ocasião jubilosa de grande relevância que mobilizava as fraternidades leigas carmelitas e franciscanas no tocante à esfera temporal uma vez que demandava recursos materiais para a realização de cerimônias e para a hospedagem do comissário visitador. No que tange ao campo espiritual a visita pastoral representava uma suspensão da rotina cotidiana e, muitas vezes, a rotura do sossego dos irmãos terceiros pois requeria uma preparação através do exame de consciência dos atos pessoais e da observação da conduta dos outros irmãos de modo que as falhas e faltas fossem apresentadas e corrigidas através de penitências, que

\footnotetext{
${ }^{34}$ AOTSF/OP - vol. 216. Livro I de receita e despesa da Ordem Terceira de São Francisco de Assis de Vila Rica - 1751 a $1812-1772 ; 1783$.
} 
poderiam resultar, em caso extremo, na expulsão do irmão da congregação caso não fossem cumpridas.

As visitas pastorais dos reverendos comissários reatualizavam entre os irmãos terceiros os princípios que fundamentavam a vivência religiosa nas ordens terceiras através da prática de exercícios de submissão e obediência e da prescrição de penitências aos irmãos acusados de algum tipo de desvio. A pompa barroca das cerimônias que marcavam a entrada do comissário visitador e que aconteciam durante as visitas produzia sobre os irmãos um efeito teatral que aguçava e comprazia os sentidos tornando-se deste modo recurso fundamental para incutir o caráter sacramental do acontecimento entre os irmãos terceiros.

\section{REFERÊNCIAS}

ARQUIVO DA ORDEM TERCEIRA DE SÃO FRANCISCO. Ordem Terceira de São Francisco de Assis de Vila Rica. Livro I de receita e despesa, v. 216, Ouro Preto, 17511812.

ARQUIVO DA ORDEM TERCEIRA DE SÃO FRANCISCO. Ordem Terceira de São Francisco de Assis de Vila Rica. Estatutos, v. 206, Ouro Preto, 1758-1761.

ARQUIVO DA ORDEM TERCEIRA DE SÃO FRANCISCO. Ordem Terceira de São Francisco de Assis de Vila Rica. Estatutos, v. 204, Ouro Preto, 1754-1756.

ARQUIVO DA ORDEM TERCEIRA DE SÃO FRANCISCO. Ordem Terceira de São Francisco de Assis de Vila Rica. Receita e despesa, v. 277, Ouro Preto,1738-1968.

ARQUIVO DA ORDEM TERCEIRA DE SÃO FRANCISCO. Ordem Terceira de São Francisco de Assis de Vila Rica. Visitas, v. 224, Ouro Preto, 1761-1765.

ARQUIVO DA ORDEM TERCEIRA DE SÃO FRANCISCO. Ordem Terceira de São Francisco de Assis de Vila Rica. Patentes, v. 513, Ouro Preto, 1745-1788.

ARQUIVO DA ORDEM TERCEIRA DE SÃO FRANCISCO. Ordem Terceira de São Francisco de São João del Rey. Livro de termos, deliberações e pastorais, São João del Rey.

ARQUIVO DA ORDEM TERCEIRA DO CARMO. Ordem Terceira de Nossa Senhora do Carmo de Vila Rica. Borrador, v. 2564, Vila Rica, 1734- 1755. 
ARQUIVO DA ORDEM TERCEIRA DO CARMO. Ordem Terceira de Nossa Senhora do Carmo de Vila Rica. Carta de Visitação, v. 2487, Vila Rica, 1761.

ARQUIVO DA ORDEM TERCEIRA DO CARMO. Ordem Terceira do Carmo de São João del Rei. Livro I de termos e deliberações, São João Del Rei.

ALGRANTI, Leila Mezan. Famílias e vida doméstica. In.: SOUZA, Laura de Mello e (Org.). Historia da vida privada no Brasil: cotidiano e vida privada na América Portuguesa. São Paulo: Companhia das Letras, 1997. p.83-154.

ARNAUT, Salvador Dias. A arte de comer em Portugal na Idade Média. Lisboa: Imprensa Nacional - Casa da Moeda, 1986.

ÁVILA, Affonso. O lúdico e as projeções do mundo barroco II: áurea idade da áurea terra. 3 ed. rev. aum. São Paulo: Perspectiva, 1994.

BÍBLIA DE JERUSALÉM. Trad. do texto em língua portuguesa diretamente dos originais. ed. rev. aum. São Paulo: Paulus, 2002.

BOSCHI, Caio César. Os Leigos e o poder: irmandades leigas e política colonizadora em Minas Gerais. São Paulo: Ática, 1986.

BLUTEAU, Rafael. Vocabulario portuguez e latino, aulico, anatomico, architectonico. v. 6. Coimbra : Real Collegio das Artes da Companhia de Jesu, 1713.

CAMPOS, Adalgisa Arantes. Irmandades mineiras e missas. Varia Historia, Belo Horizonte, n.16, p.66-76, 1996.

CAMPOS, Adalgisa Arantes; FRANCO, Renato. Aspectos da visão hierárquica no barroco luso-brasileiro:disputas por precedência em confrarias mineiras. Revista Tempo, Rio de Janeiro, n.17, p.193-215, 2004.

CARDIM, Pedro. Entradas solenes: rituais comunitários e festas políticas, Portugal e Brasil, séculos XVI e XVII. In: JANCSÓ; KANTOR. (Org.) Festa: cultura e sociabilidade na América portuguesa, v. I. São Paulo: Hucitec, 2001, p. 93-124.

EVANGELISTA, Adriana Sampaio. Pela salvação de minha alma: vivência da fé e vida cotidiana entre. os irmãos terceiros em Minas Gerais - séculos XVIII e XIX. 2010. 337 f. Doutorado (Ciência da Religião) - Faculdade de Ciências Humanas, Universidade Federal de Juiz de Fora, Juiz de Fora.

FURTADO, Júnia Ferreira. Chica da Silva e o contratador dos diamantes - o outro lado do mito. São Paulo: Companhia das Letras, 2003.

MAGALHÃES, Sônia Maria de. A mesa de Mariana: produção e consumo de alimentos em Minas Gerais (1750-1850). São Paulo: Annablume-Fapesp, 2004. 
MARAVALL, José Antonio. La cultura del barroco. Barcelona: Editorial Ariel, 1990.

MARTINS, William de Souza. Membros do corpo místico: ordens terceiras no Rio de Janeiro (c. 1700-1822). São Paulo: Edusp, 2009.

PAIVA, José Pedro. Etiqueta e cerimônias públicas na esfera da Igreja (séculos XVIIXVIII). In: JANCSÓ; KANTOR (Org.). Festa: Cultura \& Sociabilidade na América Portuguesa. v. I. São Paulo: Hucitec; 2001. p.79-93.

PASSOS, Zoroastro Viana. Em torno da História do Sabará - a Ordem Terceira do Carmo e sua igreja. Rio de Janeiro: Publicações do SPHAN, 1940.

PAZ, José da. Uma corporação religiosa vida e obra da Venerável Ordem Terceira de Nossa Senhora do Monte do Carmo, da Vila de São João del Rei. 1968. Tese (Concurso para a Cátedra de História do Colégio Estadual de Minas Gerais). Belo Horizonte.

SALES, Fritz Teixeira de. Associações religiosas no ciclo do ouro. Belo Horizonte: Imprensa da Universidade de Minas Gerais, 1963.

SCARANO. Bebida alcoólica e sociedade colonial. In: JANCSÓ; KANTOR (Org.). Festa: Cultura \& Sociabilidade na América Portuguesa. v.I, São Paulo: Hucitec, 2001. p.468-469. 